\title{
PILIERE DÔCHODKOVÉHO SYSTÉMU NA SLOVENSKU A INVESTOVANIE V DÔCHODKOVÝCH FONDOCH S VYUŽITÍM AKTUÁLNYCH DÁT ${ }^{1}$
}

\section{L’udmila Pavliková}

\section{Kl’účové slová:}

Dôchodkový systém, dôchodkové fondy, dôchodkové jednotky

\section{Key words:}

Pension system, pension funds, pension units

\begin{abstract}
Abstrakt
Dôchodkový systém je v každej krajine mierne odlišný. Odlišuje sa okrem iného menšou či väčšou účast'ou zo strany štátu prípadne súkromných spoločností pri organizovaní systému sociálneho poistenia a starobného dôchodkového sporenia. Podmienky, v ktorých takéto systémy v jednotlivých krajinách fungujú, sú rôzne, avšak nájde sa aj množstvo spoločného. Preto pri skúmaní takéhoto systému v nejakej krajine a nájdení jeho nedostatkov to môže viest' $\mathrm{k}$ aspoň čiastočnému poučeniu sa $\mathrm{v}$ inej krajine. Tento článok sa pokúša poukázat' na vybrané problémy súčasných dôchodkových systémov, ktoré vznikajú počas fungovania nových, zreformovaných dôchodkových systémov, najmä s dôrazom na dôchodkové fondy. Vzhl'adom na rozsah príspevku sú vybrané len niektoré z nich. Krajinou, v ktorej boli sledované tieto vplyvy v období posledných rokov, je Slovensko, kde sa dôchodkový systém reformoval už v roku 2004.
\end{abstract}

\begin{abstract}
Pension system is slightly different for each country. It differs, by a lesser or greater involvement by the State or private companies to organize a system of social insurance and retirement pension saving. The conditions under which such systems operate in different countries are different but in many thinks they are common. Therefore, when considering such a system in a country and finding its weaknesses, it can lead to a partial learning in other country. This article is trying to highlight the current problems of pension systems that arise during the operation of new, reformed pension systems - specially for pension funds. Given the scale of contribution, there are selected only some of them. Country, in which these effects were observed during recent years, is the Slovak Republic, where the pension system was reformed as early in 2004.
\end{abstract}

\section{Úvod}

Pred uvedením a popísaním problémových oblastí dôchodkového systému je potrebné ozrejmit', na akom princípe tento systém funguje, ako príklad je uvedená Slovenská republika.

$\mathrm{Na}$ Slovensku prebehla reforma dôchodkového systému čiastkovo, najprv sa zmenili podmienky v systéme starobného dôchodkového poistenia (r. 2003), d’alej zmeny nastali aj vytvorením systému starobného dôchodkového sporenia (r. 2004), neskôr sa reformoval aj systém doplnkového dôchodkového sporenia (r. 2008). Z legislatívneho hl'adiska pozostávala

\footnotetext{
${ }^{1}$ Príspevok riešený vrámci projektu 1/0897/2010 Meranie a riadenie úrokového rizika
} 
reforma dôchodkového systému SR z troch hlavných častí (pilierov), ktoré upravujú jednotlivé zákony.

Dôchodkové poistenie - t.j. štátny dôchodok, predstavuje tzv. prvý pilier dôchodkového systému, starobné dôchodkové sporenie druhý (kapitalizačný) pilier a dôchodkové pripoistenie tretí pilier.

Naša pozornost' je však predovšetkým venovaná kapitalizačnému (sporivému, resp. druhému) pilieru, okrajovo však aj priebežnému.

\section{Faktory pôsobiace nepriaznivo na výšku dôchodku z jednotlivých pilierov}

I. pilier

Za faktory, ktoré môžu vplývat' nepriaznivo na prvý pilier, ktorý je inak označovaný aj ako priebežný, možno považovat' o.i. napríklad demografický vývoj v krajine (stále sa zhoršujúci pomer pracujúceho obyvatel'stva oproti obyvatel'om - poberatel'om dôchodku), rastúca očakávaná dížka života obyvatel'stva, ako aj zvyšujúci sa deficit v rozpočte Sociálnej poist'ovne. Z nich vyplývajú rôzne zmeny, ktoré možno kvôli stále silnejúcim nepriaznivým vplyvom faktorov očakávat', jednou z nich je napríklad d'alší posun hranice veku odchodu do dôchodku.

V prípade prvého piliera sú faktory len vymenované, väčšia pozornost' je venovaná faktorom a ich vplyvu na druhý pilier dôchodkového systému a dôchodok z neho plynúci.

II. pilier

Najprv si vysvetlíme podstatné charakteristiky 2. piliera a z toho vyplývajúce možné problémy. Ide najmä o rôzne poplatky, ktoré musí sporitel' pravidelne platit' z prostriedkov na účte a takisto o výšku výnosu, akou sú tieto jeho úspory zhodnocované - tieto faktory možno považovat' za najdôležitejšie pri ovplyvňovaní výšky dôchodkových úspor, resp. z nich vyplácaného dôchodku.

V krátkosti uvedieme charakteristiky systému starobného dôchodkového sporenia, ktoré predstavujú dôchodkové správcovské spoločnosti (d’alej len DSS). DSS [8] je akciová spoločnost' so sídlom na území Slovenskej republiky, ktorej predmetom činnosti je vytváranie a správa dôchodkových fondov na vykonávanie starobného dôchodkového sporenia podl'a zákona č. 43/2004 Z. z. o starobnom dôchodkovom sporení.

\section{Poplatky dôchodkovej správcovskej spoločnosti}

DSS má právo na :

a) poplatok za správu dôchodkového fondu,

b) poplatok za vedenie osobného dôchodkového účtu.

Poplatok DSS za jeden mesiac správy dôchodkového fondu podl'a zákona určená v štatúte dôchodkového fondu nesmie $\mathrm{v}$ súčasnosti presiahnut' $0,025 \%$ priemernej mesačnej čistej hodnoty majetku v dôchodkovom fonde (z pôvodných 0,08 \%, neskôr 0,065 \% ). To neplatilo v období prvých troch rokov odo dňa začatia vykonávania činnosti, počas ktorého poplatok DSS podl'a prvej vety nesmela presiahnut' $0,075 \%$ priemernej mesačnej čistej hodnoty majetku v dôchodkovom fonde (z pôvodných 0,08 \%). Na základe Zákona č. 137/2009 Z. z. pribudol poplatok za zhodnotenie majetku $\mathrm{v}$ dôchodkovom fonde, ktorý za jeden mesiac správy dôchodkového fondu určený v štatúte dôchodkového fondu nesmie presiahnut' 5,6 \% z 
jednej šestiny zhodnotenia majetku v dôchodkovom fonde za sledované obdobie, ktorým sa rozumie šest' mesiacov.

Poplatok DSS za vedenie osobného dôchodkového účtu je $1 \%$ zo sumy mesačného príspevku pripísaného na bežný účet dôchodkového fondu po pripísaní dôchodkových jednotiek na osobný dôchodkový účet sporitel'a.

Od júla 2009 je stanovené obdobie sledovania zhodnotenia majetku v dôchodkovom fonde pre určenie výšky poplatku za jeho zhodnotenie a povinnosti dopĺn̆at' majetok $\mathrm{v}$ dôchodkových fondoch na šest' mesiacov. Nový spôsob garancie dôchodkových úspor znamená, že DSS ochráni úspory občana pred poklesmi na trhoch. Výnosy v každom type fondu budú DSS podl'a nových pravidiel sledovat' a porovnávat' každý mesiac. Ak dôjde k poklesu, príslušný rozdiel do fondu doplatí podl'a zákona konkrétna DSS. Ak investovanie prinesie vyššie zhodnotenie, bude mat' sporitel' aj viac peňazí na účte a tým aj vyšší dôchodok z 2. piliera.

Novinkou v prospech sporitel'a je vytvorenie garančného účtu pri každom dôchodkovom fonde. Je to vlastne schránka, v ktorej sa kumulujú potenciálne výnosy. V prípade, že dosiahnu určitú hranicu, bude mat' DSS nárok na čerpanie z neho vo forme poplatku. Ak by bolo zhodnotenie za sledované obdobie záporné, bude DSS musiet' rozdiel dorovnat' z garančného účtu a pokial' by na to prostriedky na garančnom účte nepostačovali, tak aj z vlastného majetku. Čo znamená, že v každom type fondu bude DSS mesačne sledovat' a porovnávat' výnosy. Ak dôjde $\mathrm{k}$ poklesu, DSS doplatí do fondu príslušný rozdiel podl'a zákonom určených pravidiel.

Dôchodková správcovská spoločnost’ vytvára a spravuje :

1. jeden rastový dôchodkový fond,

2. jeden vyvážený dôchodkový fond,

3. jeden konzervatívny dôchodkový fond,

Dôchodkové fondy, uvedené vyššie, sa odlišujú v investovaní majetku v dôchodkovom fonde podl'a :

- druhu investičných nástrojov, ktorým sa má zabezpečit' zväčšenie majetku v dôchodkovom fonde,

- $\quad$ vytvoreným portfóliom,

- $\quad$ miery rizika zhodnocovania majetku v dôchodkovom fonde,

- $\quad$ v názve.

Dôchodkový fond začína DSS vytvárat' v okamihu pripísania prvého príspevku na bežný účet dôchodkového fondu u depozitára.

\section{Dôchodková jednotka a čistá hodnota majetku}

Dôchodková jednotka je podiel na majetku v dôchodkovom fonde. Hodnota dôchodkovej jednotky sa vyjadruje $\mathrm{v}$ slovenských korunách a určuje sa s presnostou na štyri desatinné miesta. Prvý deň, ked' DSS začne vytvárat' dôchodkový fond, je počiatočná hodnota dôchodkovej jednotky 0,033194 Eur (pôvodne 1 Sk). Po tomto dni sa určuje aktuálna hodnota dôchodkovej jednotky.

Aktuálna hodnota dôchodkovej jednotky v deň výpočtu sa určí ako podiel čistej hodnoty majetku v dôchodkovom fonde a počtu všetkých dôchodkových jednotiek evidovaných na 
osobných dôchodkových účtoch všetkých sporitel'ov dôchodkového fondu $\mathrm{v}$ deň výpočtu (k dátumu 03.-12.10.2011 je aktuálna dôchodková jednotka pre vybraný vyvážený fond $\mathrm{v}$ jednotlivých DSS uvedený na grafe č. 3 v časti 2 . Aktuálny stav v číslach)

Čistá hodnota majetku $\mathrm{v}$ dôchodkovom fonde je rozdiel medzi hodnotou majetku $\mathrm{v}$ dôchodkovom fonde a jeho záväzkami.

Aktuálna hodnota dôchodkovej jednotky v deň výpočtu sa určí ako podiel čistej hodnoty majetku v dôchodkovom fonde a počtu všetkých dôchodkových jednotiek evidovaných na osobných dôchodkových účtoch všetkých sporitel'ov dôchodkového fondu v deň výpočtu.

Čistú hodnotu majetku v dôchodkovom fonde a aktuálnu hodnotu dôchodkovej jednotky je DSS povinná vypočítat' každý pracovný deň a oznámit’ NBS a depozitárovi.

\section{Investovanie majetku v dôchodkových fondoch}

Investovanie je zhodnocovanie majetku v dôchodkovom fonde, kde sa zákonom vymedzuje:

- $\quad$ spôsobom akým sa tento majetok investuje,

- do akého majetku sa investuje,

- princíp obmedzenia a rozloženia rizika.

Majetok v dôchodkovom fonde môže byt' použitý iba s ciel'om zabezpečit' riadne a bezpečné investovanie majetku v dôchodkovom fonde a ochranu sporitel'ov a poberatel'ov dôchodku starobného dôchodkového sporenia.

\section{Druhy fondov}

\section{Konzervatívny dôchodkový fond}

Majetok v konzervatívnom dôchodkovom fonde:

- $\quad$ sa môže použit' len na dlhopisové a peňažné investície a na obchody na obmedzenie menového rizika;

- $\quad$ musí byt' v plnej výške zabezpečený voči menovému riziku;

- môže dosahovat’ maximálnu priemernú modifikovanú duráciu v hodnote 2. Priemerná modifikovaná durácia na účely tohto zákona vyjadruje pomer zmeny hodnoty majetku v dôchodkovom fonde pri jednotkovej zmene úrokovej sadzby, ktorá priamo alebo nepriamo ovplyvňuje hodnotu majetku v dôchodkovom fonde.

Vyvážený dôchodkový fond

- Hodnota akciových investícií môže spolu tvorit' najviac 50 \% hodnoty majetku vo vyváženom dôchodkovom fonde.

- Hodnota dlhopisových a peňažných investícií musí spolu tvorit’ najmenej 50 \% hodnoty majetku.

- $\quad$ Majetok, ktorý nie je zabezpečený voči menovému riziku, môže predstavovat' najviac $50 \%$ hodnoty majetku.

\section{Rastový dôchodkový fond}

- $\quad$ Hodnota akciových investícií môže spolu tvorit’ najviac 80 \% hodnoty majetku

- Majetok, ktorý nie je zabezpečený voči menovému riziku, môže predstavovat' najviac $80 \%$ hodnoty majetku.

[8], [9], [10] 


\section{Aktuálny stav v číslach}

K 31.12.2010 si v 2. pilieri sporilo 1442058 l’udí. Na svojich osobných dôchodkových účtoch vlastnili k tomuto dátumu 3 717,9 mil. Euro. Na Slovensku v tomto období pôsobilo šest' DSS.

Na grafe č. 1 vidiet', že napriek nastaveniu podmienok v jednotlivých fondoch (z hl'adiska delenia na rastové, vyvážené a konzervatívne) tak, aby boli rastové fondy najvýkonnejšie, je situácia v ostatných rokoch práve opačná, kde konzervatívne fondy dosahujú vo väčšine DSS vyššie výnosy, ako je tomu pri rastových fondoch. Dôvodom je skladba portfólií a opatrnejšie investovanie, ktoré v prípade obdobia krízy od roku 2008, kde sa tento obrat začínal prejavovat', znamenalo aj väčšie výkyvy smerom do záporných čísel.

Graf č. 1 Nominálne zhodnotenie v konzervatívnom, vyváženom a rastovom DF

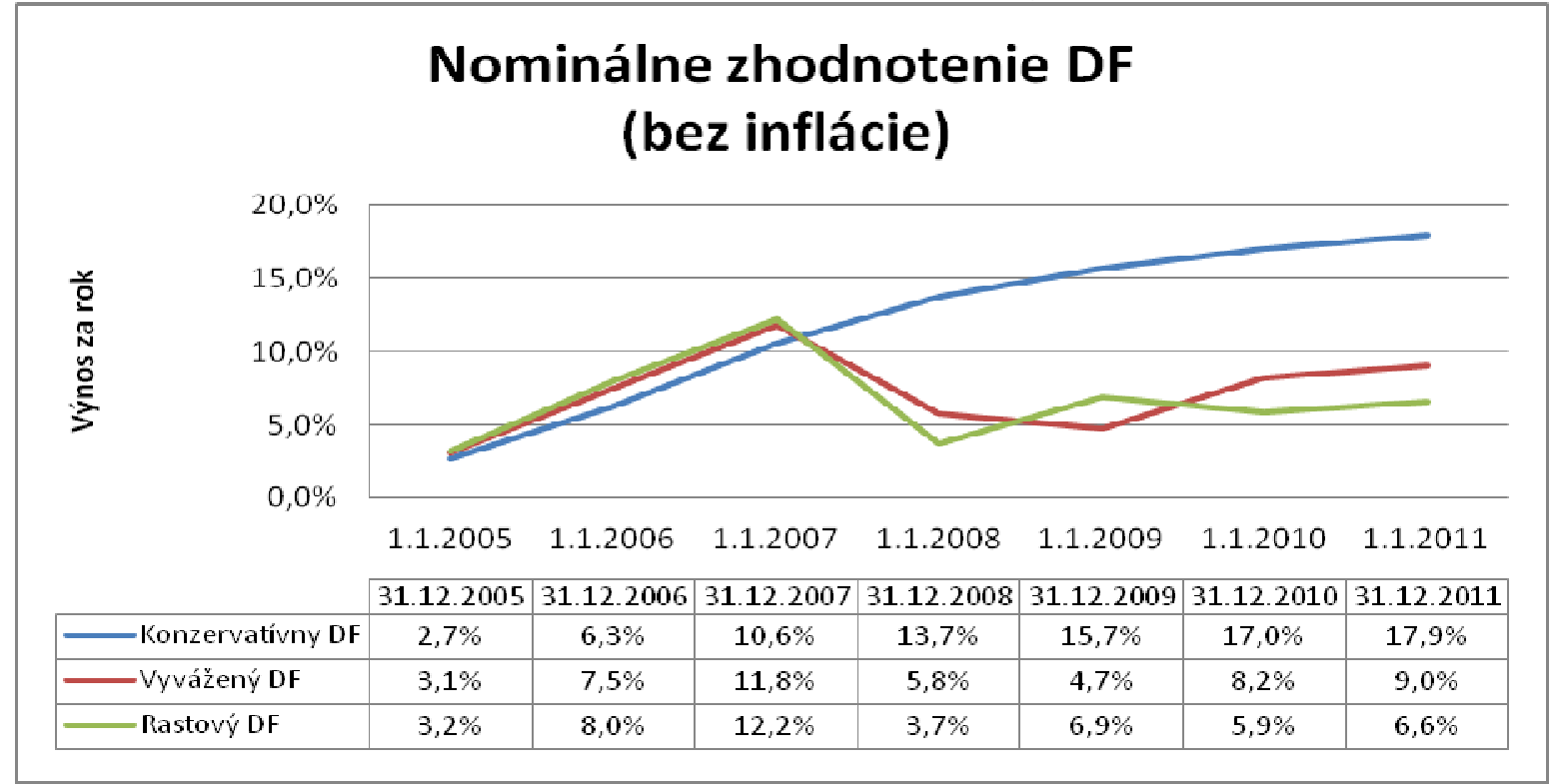

Prameň: vlastné spracovanie na základe [19]

Graf č. 2 Reálne zhodnotenie v konzervatívnom, vyváženom a rastovom DF

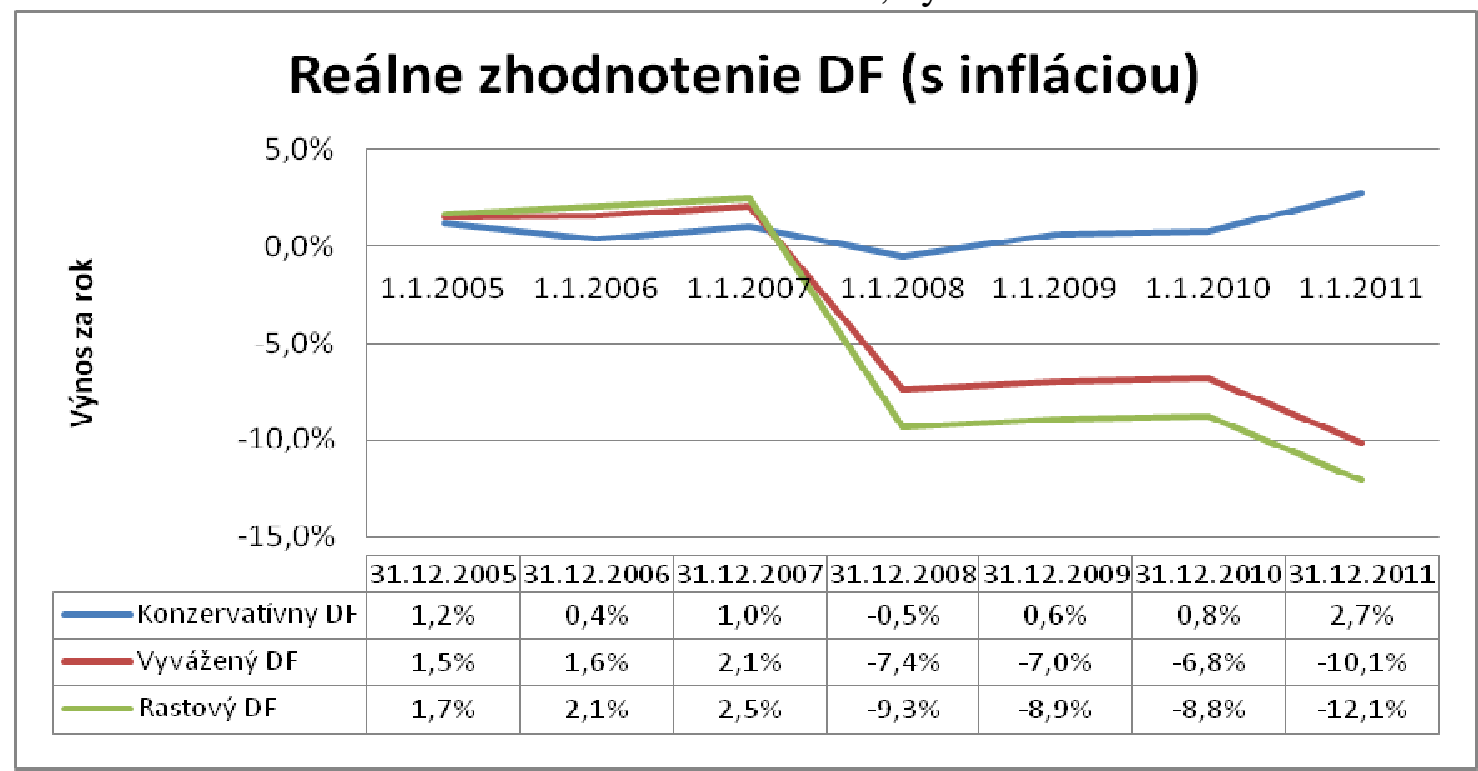

Prameň: vlastné spracovanie na základe [19] 
Z grafu č. 1 je zrejmé, aké majú jednotlivé typy DF nominálne zhodnotenie, ktoré je v ostatnom čase v kladných hodnotách, no pokial' by sme vzali do úvahy aj zreálnenie týchto zhodnotení vplyvom inflácie, dospeli by sme k reálnemu zhodnoteniu, ktoré je vidiet' na grafe č. 2 , kde sú už zhodnotenia aj záporné Pre sporitel'a to znamená, že výnosy nepokryjú ani hodnotu inflácie a tak je otázne, či úspory, z ktorých sa neskôr budú vyplácat' starobné dôchodky, postačia na zabezpečenie primeranej úrovne príjmu v období staroby.

Pre porovnanie výkonnosti jednotlivých DSS sa uvádzajú aj dôchodkové jednotky (d’alej len DJ). Pre názornost' sme vybrali DF vyvážené, ktoré z hl'adiska rizika a výnosnosti sú akýmsi stredom. Na grafe č. 3 vidiet', že DJ sa v ostatných dňoch (platí k dátumu 19.10.2011) pohybovali pri najvýkonnejšom fonde okolo 3,69 \% (VÚB Generali, d.s.s., a.s.) a pri najmenej výkonnom 3,55 \% (ČSOB, d.s.s. a.s.). Dlhodobo však najpozitívnejšie výkonnosti dosahujú ešte stále konzervatívne DF, v ostatných dňoch sa výnosy v týchto fondoch pohybujú stále okolo 3,95\%.

Graf č. 3 Aktuálna hodnota dôchodkovej jednotky vo vyváženom type DF vo všetkých DSS

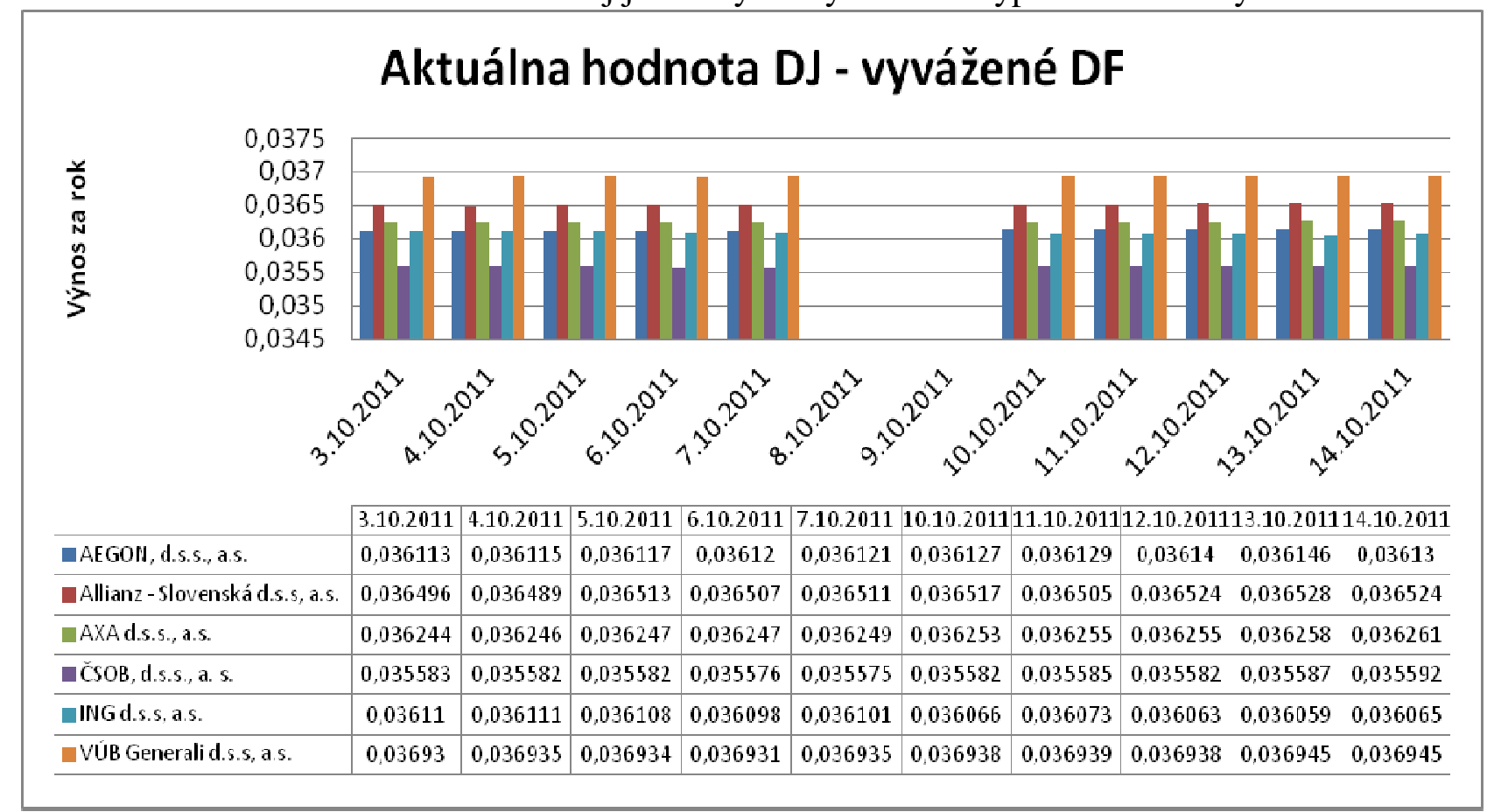

Prameň: vlastné spracovanie na základe [19]

V roku 2010 je za najvýkonnejšiu DSS považovaná VÚB Generali, ktorá vo všetkých troch typoch DF dosahovala najväčšie výnosy spomedzi ostatných DSS. Je to zrejmé z grafu č. 4.

Rôzne veličiny (ročná výkonnost’ DSS, vývoj DJ) pre posúdenie výkonnosti jednotlivých DF v DSS nám poukazujú na to, že výkonnosti sa pri jednotlivých DSS v doterajšom období pohybovali viacmenej na rovnakej úrovni, dokonca podobným spôsobom sa dostávali aj do záporných čísel. V skutočnosti však žiadna z výnosností výrazne neprevyšuje úroveň inflácie v danom roku. Preto výnosnost', ktorou sa zhodnocujú prostriedky na sporiacom dôchodkovom účte, môže v reálnom vyjadrení znamenat' zníženie hodnoty nasporenej sumy. To môže pre sporitel'a znamenat' nedostatočné prostriedky pre obdobie, ked' sa mu z nasporenej sumy má začat' vyplácat' dôchodok. 
Graf č. 4 Porovnanie ročnej výkonnosti DSS

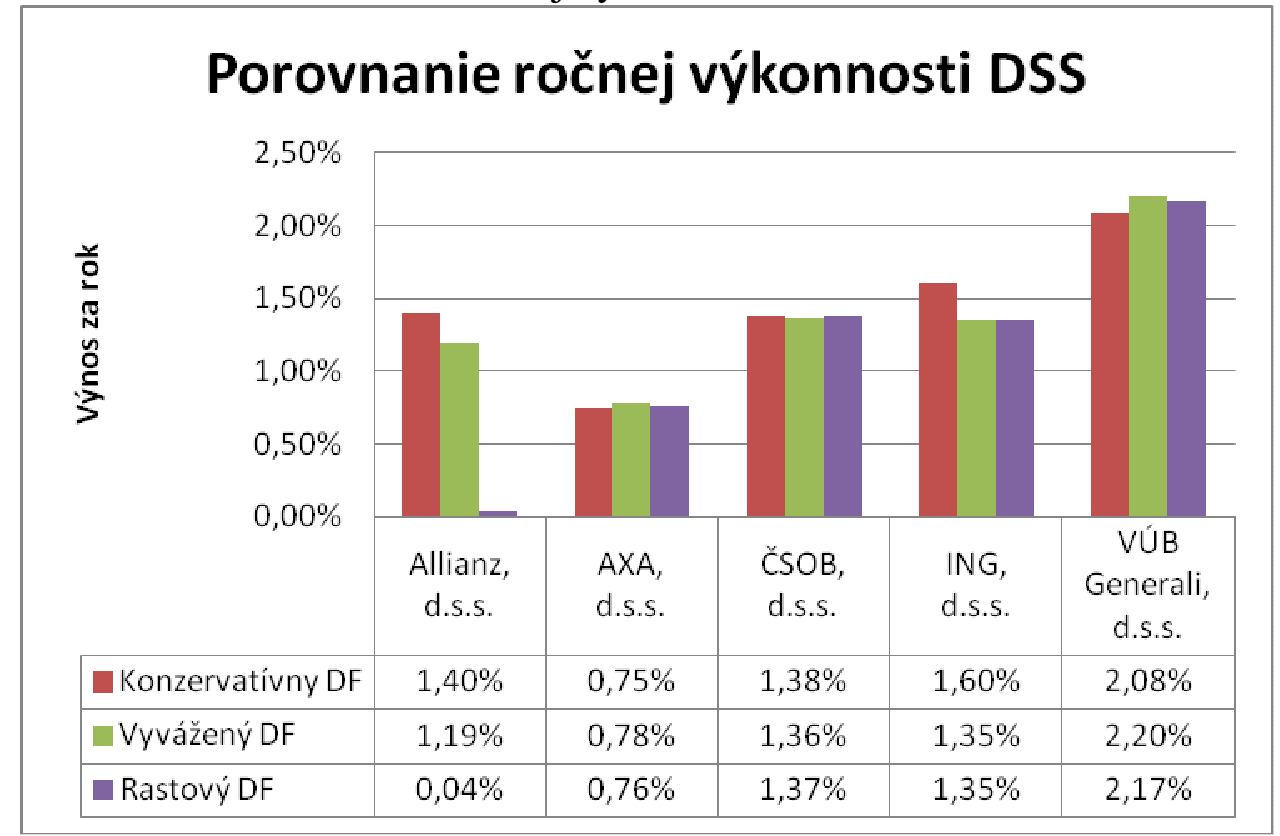

Prameň: vlastné spracovanie na základe [19]

Výnosy spolu úzko súvisia s poplatkami, ked’že aj dostatočne vysoké výnosy môžu byt' výrazne znižované vysokými poplatkami, ktoré si účtujú DSS. Zaujímavou je skutočnost', že spočiatku, ked' spoločnosti chceli nalákat' klientov, mali mnohé z nich pre svoje fondy poplatok za správu aktív v nulovej výške. Dnes už žiadna zo spoločností nevyužíva možnost' stanovenia tohto poplatku na inú ako maximálnu zákonom stanovenú hranicu. V začiatkoch, počas krátkeho obdobia fungovania DSS tento poplatok neznamenal vel'a, pretože za pár mesiacov aj tak na účtoch sporitel'ov nebolo naakumulovaných vel'a finančných prostriedkov, z ktorých sa tento poplatok počítal. Od 1. júla 2009 je poplatok za správu aktív zákonom stanovený na najviac $0,25 \%$ a od tejto doby ho žiadna spoločnost’ nemá v nižšej hodnote.

Akú významnú úlohu pri ovplyvnení výšky úspor má tento poplatok z dlhodobého hl'adiska, si môžeme uviest' na nasledujúcom modelovom príklade.

\section{Modelový príklad}

Modelový príklad výpočtu dôchodku z prvého a druhého piliera je nadefinovaný pre sporitel'a, ktorý vstúpil do nového systému v 30.-tom roku svojho života, v roku 2005. Modelový príklad je zobrazený na grafe č. 5 na základe nižšie uvedených predpokladov. Ked’že význam poplatku, ktorý sa uvažuje od 4.roku fungovania DF je výraznejší oproti poplatku do 3.roku, počítali sme vplyv práve tohto poplatku na konečnú výšku dôchodkových úspor.

Nárast priemernej mzdy a možné výkonnosti fondov v d’alších rokoch sme neodhadovali samostatne, zohl'adnili sme možný vývoj na základe odhadov z dvoch hlavných zdrojov, z ktorých sme vychádzali (Ministerstvo práce, sociálnych vecí a rodiny (MPSVaR) a INEKO). Stručne možno zhrnút', že oba zdroje predpokladali reálny rast priemernej mzdy okolo 3,50\%, v odhadoch ročnej reálnej výnosnosti v II. pilieri sú ich odhady vzdialenejšie, pri oboch ukazovatel'och však možno odhady MPSVaR považovat' za optimistickejšie. 
Vychádzalo sa z predpokladov:

- $\quad$ mzda jednotlivca vo výške priemernej nominálnej mzdy (v r. 2005 - 573,3918 Eur);

- $\quad$ vek odchodu do dôchodku 62 rokov;

- $\quad$ odvody do oboch pilierov sú rovnaké - devät' percent,

- $\quad$ poplatok Sociálnej poist'ovni za vedenie účtu 0,5 percent mesačne;

- $\quad$ poplatok DSS za vedenie osobného dôchodkového účtu vo výške jedno percento;

- $\quad$ poplatok za správu aktív na účte sporitel'a v období prvých troch rokov činnosti je 0,08 percent mesačne.

Meniaci sa parameter: poplatok za správu aktív od štvrtého roka činnosti DSS. Uvažovali sme, že tento poplatok by mohol byt' zákonom zmenený, mohlo by dôjst' k jeho zvýšeniu preto sme pre výpočet použili hodnoty od nula do pät' percent, postupne po 0,2 .

Graf č. 5 Vplyv poplatku za správu aktív od 4.roku fungovania DSS na výšku dôchodkových úspor sporitel'a

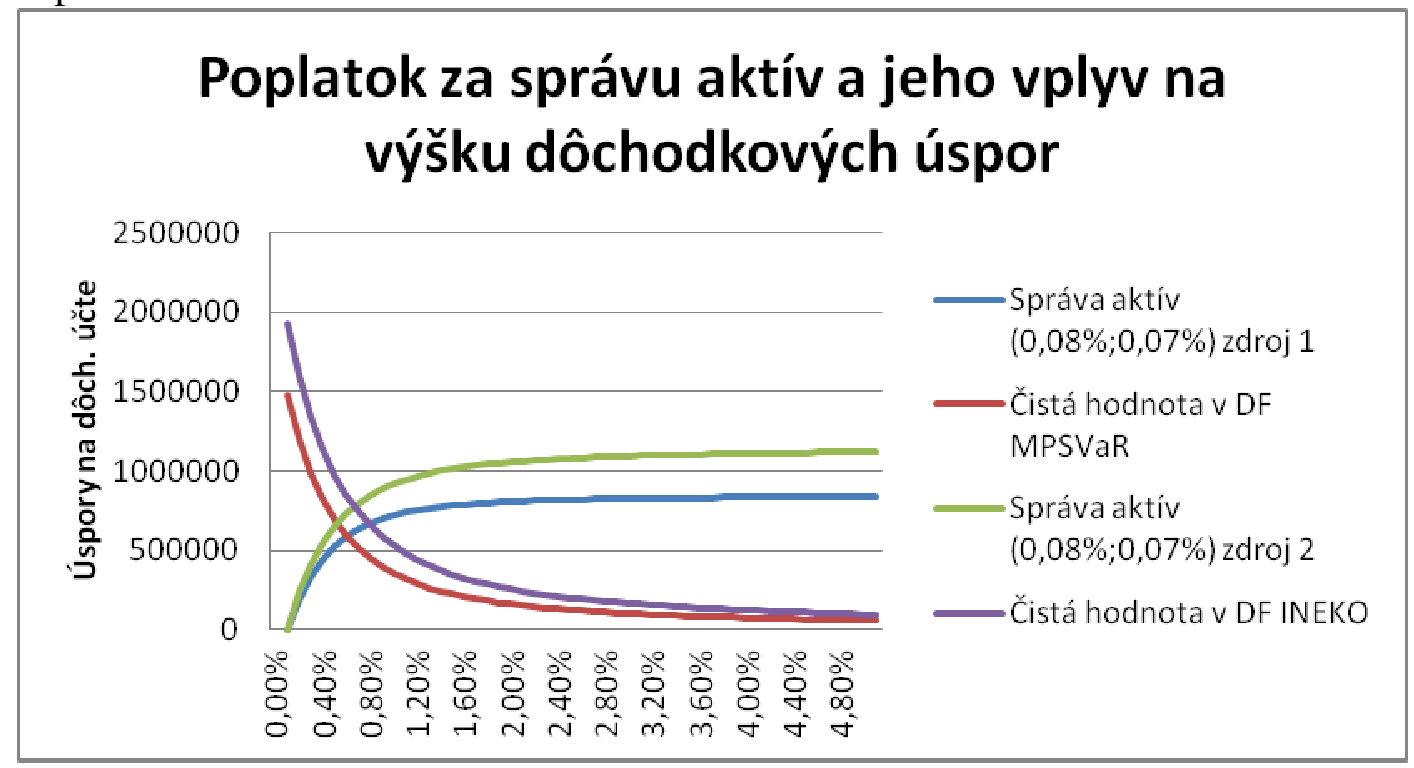

Prameň: Výpočty a grafická úprava vlastná.

Ako vidiet' na grafe č. 5 spočiatku strmo rastúci charakter poplatkov za správu aktív, ako aj všetkých poplatkov, sa v určitom okamihu zmení na takmer nemennú hodnotu poplatkov pri meniacej sa percentuálnej výške poplatku za správu aktív. Súvisí to pravdepodobne s očakávaným zhodnotením vložených prostriedkov, ktoré je súčast'ou našich predpokladov. Ked’že zhodnotenie sa uvažuje vo výške okolo 3,5 percent v oboch prípadoch, v určitej výške poplatku za správu aktív dochádza k situácii, ked' začínajú byt' poplatky v takej výške, že pohlcujú výnosy a tak ani objem úspor, z ktorých sa počítajú, v skutočnosti vel'mi nenarastá a teda nemajú z čoho narastat' ani poplatky, napriek zvyšujúcej sa percentuálnej sadzbe poplatkov za správu aktív. S celkovým vývojom spomínaných poplatkov súvisí aj vývoj čistej hodnoty na účte v dôchodkovom fonde. Spočiatku, pri nulovom poplatku, je v dôchodkovom fonde 48918,59 Eur (MPSVaR), resp. 64195,34 Eur (INEKO).

Postupne, ako sa zvyšuje poplatok za správu aktív, sa rýchlym tempom znižuje hodnota na účte sporitel'a. V určitom okamihu, ktorý súvisí s vyššie spomenutým zlomom vo vývoji poplatkov, dochádza $\mathrm{k}$ miernejšiemu poklesu tejto čistej hodnoty v dôchodkovom fonde. Pri pät' percentnom poplatku sa hodnota úspor zníži na 1878,441 Eur (MPSVaR), resp. 3130,534 Eur (INEKO). Na prvý pohl'ad môže íst' o prekvapujúco nízke hodnoty, avšak logické 
zdôvodnenie možno naozaj hl'adat' $\mathrm{v}$ tom, že zvyšujúce sa poplatky pri nemeniacich sa nízkych výnosoch spôsobia straty, a tak sporitel' na účte nemá ani súčet svojich jednotlivých vkladov, ktoré si na účet v rokoch postupne odvádzal. Možno v budúcnosti nedôjde až $\mathrm{k}$ takému výraznému zvýšeniu poplatkov, ako je to zobrazené v pravej časti grafu, no treba si uvedomit', že podobný efekt, ako zvýšenie poplatkov pri nemeniacich sa výnosoch, ktoré môže ohrozit' konečnú hodnotu úspor, môžu spôsobit' aj menšie výnosy pri nemeniacich sa poplatkoch.

\section{Záver}

Záverom možno konštatovat', že už počas krátkej doby fungovania zreformovaného dôchodkového systému na Slovensku má na výšku dôchodkových úspor nepriaznivý vplyv mnoho faktorov. Ťažko určit', ako sa na výške dôchodku z priebežného systému prejaví demografický vývoj v dlhodobom období, a teda či naozaj budú ohrozené sl'úbené budúce dôchodky. Ani zabezpečením si dôchodku zo sporivého piliera si však občan nemôže byt' stopercentne istý, ako to s jeho dôchodkom bude vyzerat'. Už počas vel'mi krátkeho obdobia boli dôchodkové jednotky (na ktoré priamo vplývajú poplatky a výnosy v tomto systéme) poznačené jednak krízou na finančných trhoch vo svete, d'alej zmenou skladby portfólií jednotlivých fondov, zvyšovaním, či v lepšom prípade znižovaním poplatkov v príslušných fondoch, ako isto aj inými faktormi, ktoré sme vzhl'adom na informačnú nedostupnost' nespomenuli. Všetky tieto vplyvy spôsobujú zmeny v dôchodkových úsporách občana. Uvedené boli najmä vplyvy, ktoré dôchodkové úspory znižujú a tým nepriaznivo pôsobia na výsledný efekt z tohto systému a preto ich v konečnom dôsledku možno považovat' za problémovú oblast' mnohých súčasných dôchodkových systémov.

\section{Literatúra:}

[1] BARTKOVÁ, D. Makro a mikroekonomické súvislosti dôchodkovej reformy na Slovensku. Košice: Mladí vedci, 2005.

[2] PAVliKOVÁ, L'. - Raisová, M. Porovnanie spoločností poskytujúcich starobné dôchodkové sporenie na Slovensku na základe vybraných kritérií. Košice: Národná a regionálna ekonomika 7, 2008, s. 738-744.

[3] PAVLIKOVÁ, L'. Analýza predpokladov zhodnocovania finančných prostriedkov v DSS na Slovensku. Košice: Dizertačná práca, 2008.

[4] PAVLIKOVÁ, L. Vplyv poplatkov a výnosov na konečnú výšku dôchodku jednotlivca. Ostrava: MEKON, 2007.

[5] ŠOLTÉS, V. - VARGOVÁ, L. Problémy vyplývajúce z dôchodkovej reformy prvého piliera. Integračný proces a jeho vplyv na verejné a podnitel'ské financie. 2006, s. 453457.

[6] ŠOLTÉS, V. Analýza prvého piliera dôchodkovej reformy v Slovenskej republike. Hradecké ekonomické dny, 2006, s. 493-497.

[7] VRAVEC, J. Analýza dôchodkových fondov v SR. Košice: Národná a regionálna ekonomika 7, 2008. s. 938-945.

[8] Zákon č. 43/2004. o starobnom dôchodkovom sporení

[9] Zákon č. 461/2003 o sociálnom poistení

[10] Zákon č. 137/2009 ktorým sa mení a doplńa zákon č. 43/2004 o starobnom dôchodkovom sporení.

Internetové stránky jednotlivých DSS

[11] www.adss.sk 
[12] www.aegon.sk

[13] www.asdss.sk

[14] http://www.axa-sk.com/axa-dss/

[15] www.csobdss.sk

[16] www.ingdss.sk

[17] www.vubgenerali.sk

[18] http://www.nbs.sk/sk/dohlad-nad-financnym-trhom/dohlad-nad-dochodkovymsporenim/aktualna-hodnota-dochodkovej-jednotky-a-cista-hodnota-majetku-vdochodkovom-fonde/vyvoj-aktualnej-hodnoty-dss/aktualna-hodnota-dochodkovej-dss

[19] http://www.employment.gov.sk/index.php?SMC=1\&id=17870

Klasifikácia JEL: G23

Ing. L'udmila Pavliková, PhD.

Katedra bankovníctva a investovania

TU v Košiciach, Ekonomická fakulta

Nemcovej 32, Košice

Ludmila.Pavlikova@tuke.sk 